\title{
CHANGES ON THE BIOAVAILABILITY OF DDT IN SOIL BY ADDITION OF LIGNITE AND COAL SOLUBILIZING BACTERIA
}

\author{
Kerry Johana DÍAZ-FUENMAYOR ${ }^{1}$, Manuel PANTOJA-GUERRA ${ }^{2 *}$, \\ Ricardo A. TORRES-PALMA ${ }^{3}$ and Nelson Valero ${ }^{1}$
}

\footnotetext{
${ }^{1}$ Facultad de Ciencias Básicas y Aplicadas, Universidad de La Guajira. Bloque IV, 3er. piso. Kilómetro 5 vía Maicao - Riohacha. La Guajira, Colombia

${ }^{2}$ Grupo de Investigación Microbiología Agrícola y Ambiental, Departamento de Microbiología, Universidad Popular del Cesar, Sede Sabanas. Campus Universitario, bloque G, 4to. piso. Avenida Fundación, Diagonal 21 No. 29-56. Valledupar, Colombia

${ }^{3}$ Grupo de Investigación en Remediación Ambiental y Biocatálisis, Instituto de Química, Facultad de Ciencias Exactas y Naturales, Universidad de Antioquía. Calle 70 No. 52-21, Medellín, Colombia

* Corresponding author: manuelpantojag@unicesar.edu.co
}

(Received February 2016; accepted September 2016)

Key words: low rank coal, adsorption, humified organic matter, decontamination

\begin{abstract}
DDT is an organochlorine insecticide that is persistent and exhibits residuality in the environment. This study assessed the effect of the application of lignite [low rank coal (LRC)] and coal solubilizing bacteria (CSB), on the bioavailability of DDT in soil with low organic matter content. In doing this, three trials were designed; in the first trial, soil samples were treated with CSB and LRC for 30 days and, afterwards, they were immersed in a DDT solution at water solubility limit and, lastly, the remaining DDT in the aqueous solution was determined. In the second trial, soil samples previously contaminated with DDT were treated with LRC and CSB. After 30 days of this interaction, the soil samples were immersed in water and the remaining DDT in solution was subsequently determined. The third trial was similar to the latter, but the interaction lasted for six months. In the first experiment, treatments with LRC and LRC + CSB, showed 8.16 and $3.4 \%$ of remaining DDT respectively, thus indicating the retention of the compound in the soil. In the second trial, the treatment with CSB greatly reduced the bioavailable DDT $(0.007 \mathrm{ppm})$, compared to the control $(0.014 \mathrm{ppm})$; this is possible since these bacteria use DDT as a carbon source. In the third trial, the highest reduction in the bioavailability of DDT took place in LRC and LRC + CSB treatments; this trial also detected DDD produced from DDT transformation, which showed the same behavior; the interaction timeframe favors adsorption and copolymerization of pollutants to humified organic matter (HOM) in soil. Use of LRC as a source of HOM represents a promising strategy for the treatment of soils with low organic matter content affected by persistent organic pollutants such as DDT.
\end{abstract}

Palabras clave: carbón de bajo rango, adsorción, materia orgánica humificada, descontaminación 


\section{RESUMEN}

El DDT es un insecticida organoclorado, es persistente y presenta residualidad en el ambiente. En este trabajo se evaluó el efecto de la aplicación de lignito [carbón de bajo rango (CBR)] y bacterias solubilizadoras de carbón (BSC), sobre la biodisponibilidad de DDT en un suelo con bajo contenido de materia orgánica. Para conseguirlo se hicieron tres experimentos; en el primer ensayo las muestras de suelo fueron tratadas con BSC y CBR por 30 días, después fueron sumergidas en una solución de DDT al límite de solubilidad en agua, posteriormente se determinó el DDT remanente en la solución acuosa. En un segundo ensayo, las muestras de suelo, contaminadas previamente con DDT, fueron tratadas con CBR y BSC. Después de 30 días de interacción las muestras de suelo fueron sumergidas en agua y fue determinado el DDT remanente en la solución. El tercer ensayo fue similar al anterior, pero el tiempo de interacción fue de seis meses. En el primer experimento, los tratamientos con CBR y CBR + BSC, presentaron un porcentaje de DDT remanente de 8.16 y $3.4 \%$ respectivamente, esto indica la retención del compuesto en el suelo. En el segundo ensayo, el tratamiento con BSC redujo significativamente el DDT biodisponible (0.007 ppm), comparado con el control (0.014 ppm); es posible que estas bacterias utilicen DDT como fuente de carbono. En el tercer experimento, los tratamientos con CBR y CBR + BSC presentaron la mayor reducción en la biodisponibilidad de DDT, en este ensayo también se detectó el DDD generado a partir de la transformación del DDT, el cual mostró el mismo comportamiento; el tiempo de interacción favorece la adsorción y copolimerización de los contaminantes a la materia orgánica humificada $(\mathrm{MOH})$ del suelo. El uso de $\mathrm{CBR}$ como fuente de $\mathrm{MOH}$ representa una estrategia promisoria para el tratamiento de suelos con bajo contenido de materia orgánica afectados por contaminantes orgánicos persistentes, tales como DDT.

\section{INTRODUCTION}

DDT [1, 1, 1 - trichloro - 2,2-bis (4-chlorophenyl) ethane] is a synthetic insecticide that was widely used in the control of malaria and other mosquito-borne diseases. However, its use was banned in most countries because of its negative effects on human health and ecosystems. Despite its ban, DDT is ubiquitous and, due to its persistence, was recently reported as a contaminant in land ecosystems (Purnomo et al. 2011). In 1993 the use and marketing of DDT was banned in Colombia; however, in Caracolicito Village (municipality of El Copey), department of Cesar, the accumulation and persistence of DDT have been reported as well as other insecticides in land for agricultural use abandoned since the 1960s (Ministerio de Medio Ambiente 2007). This municipality began its cotton farming activity since 1953, and the use of pesticides to control blights was intense until the beginning of the $90 \mathrm{~s}$, when there was a drastic reduction in production, which left a surplus of unused pesticides, such as methyl parathion, ethyl parathion, endosulfan, lead arsenic, and dichlorodiphenyltrichloroethane (DDT). These compounds were buried, allowing them to get mixed with the soil and increasing their residuality (Sánchez et al. 2006, Rojas 2010). For remediation of soil contaminated with DDT, several physicochemical and biological technologies have been tested; as a mechanism for bioremediation, bacterial degradation of xenobiotic substances in pure cultures has been studied, but there have been problems in field trials due to factors related to high concentrations of the contaminant and ignorance of the effect of soil factors such as texture, organic matter content, availability of electron acceptors, $\mathrm{pH}$ and the presence of toxic intermediate metabolites (Sudharshan et al. 2012).

On the other hand, the reduction of DDT and its toxicity have been proposed through its immobilization in the soil's HOM fraction by means of using organic amendments (Dercova' et al. 2007). Besides reducing bioavailability, it has also been shown that the use of organic amendments increases the rate of biodegradation of organic pollutants in the soil (Stehlickova et al. 2009). The ability of soil to retain organic pollutants is attributed to adsorption phenomena and to chemical reactions that occur on the surfaces of humic substances (HS) and mineral particles (Gevao et al. 2000, Fava et al. 2004).

Hydrophobic pollutants such as DDT and other polychlorinated biphenyls become more soluble in the hydrophobic domains of HS, thus providing bioremediation processes (Fava and Piccolo 2002). It has been reported that the addition of amendments 
rich in humic substances can reduce the bioavailability of chlorpyrifos in soil up to $39.2 \%$, and also reduce its toxicity. This effect has been attributed to the adsorption capacity of humic acids (Tejada et al. 2011). Robertson and Alexander (1998) attributed the reduction of DDT toxicity to its adsorption onto the soil organo-mineral fraction, while Tomaszewski et al. (2007) found a reduction of $83 \%$ of the bioavailability of DDT in sediments from San Francisco Bay (California, USA) due to the addition of activated carbons. The reduction of DDE bioavailability has also been associated with the adsorption phenomena in soil humic fraction after application of humic amendments (Peters et al. 2007).

Moreover, it has been concluded that low rank coal (LRC) generated as a byproduct of mining opencast coal is a suitable raw material for the extraction of HS (Gianoulli et al. 2008, Valero 2013) and its direct application to the soil could be a promising strategy to increase the content of HOM and improve some conditions of soils with low organic matter content (Herrera et al. 2012). Valero et al. (2014) reported the production of HS from LRC through the activity of bacterial strains obtained from microhabitats influenced by coal mining; HOM content in soils damaged, even those affected by contaminants such as DDT, could be increased by using coal solubilizing bacteria (CSB), which possess the ability to release HOM from LRC. Also, the potential of oxihumolitic LRCs has been described, such as environmental scrubbers, having the ability to retain heavy metals and organochlorine compounds by adsorption; this effect was attributed to the reactivity of certain functional groups of HS contained within such coals (Janoš et al. 2011). This study sought to determine the effect of the application of LRC and coal solubilizing bacteria (CSB) on the bioavailability of DDT in agricultural soil of the department of Cesar, under laboratory conditions.

\section{MATERIALS AND METHODS}

The effect of the joint addition of LRC and CSB to the soil was determined on the bioavailability of DDT in laboratory conditions; in doing that, three experiments were conducted; the first one assessed the effect of pretreating soil samples with LRC and CSB on the immediate absorption of the contaminant by mixing the treated soil in a DDT concentrated solution up to the water solubility limit; in the second experiment, soil samples were contaminated with DDT and were allowed to interact with the contaminant for 30 days in order to observe the effect of the direct interaction of the pollutant with the soil during this time; the third experiment was similar to the second one, but DDT interaction with the soil and the different treatments lasted for six months. Additionally, the ability of CSB to take DDT as a carbon source was determined in order to inquire about the effect of these bacteria on the availability of DDT.

Soil. Samples from the first 20 centimeters of depth from agricultural soil were utilized, without any history of pesticide use, from Caracolicito village (municipality of El Copey) southwest of the city of Valledupar (northern Colombia). The soil was the subject of a description that included: texture (Boyoucus method), $\mathrm{pH}$ (potentiometry), exchangeable acidity (by extraction with $\mathrm{KCl}$ ), organic carbon (Walkley Black method), total nitrogen (Kjeldahal method) and cation exchange capacity (by extraction with $1 \mathrm{~N}$ ammonium acetate and neutral).

LRC and humic acids (HA). Lignite-type LRC obtained from an open cast mine known as El Cerrejón in La Guajira, Colombia was used. LRC was crushed and sieved through a $300 \mu \mathrm{m}$ pore diameter sieve and then supplied into the soil. The elemental characterization of LRC was performed with an EAI CE-440 elemental analyzer following the ASTM D5373 method.

Humic acids (HA) were obtained from LRC by means of the alkaline extraction classical method with $0.5 \mathrm{~N} \mathrm{NaOH}$ (Sharif et al. 2002); for the extraction, work was done at a 1:10 ratio (w/v) of [LRC]/ $[1 \mathrm{~N} \mathrm{NaOH}]$. This mixture was kept at $100^{\circ} \mathrm{C}$ for 10 hours; upon completion of the extraction process, it was allowed to rest for 24 hours and the total humic extract (THE) was obtained.

The separation of HA from THE was done carrying THE up to $\mathrm{pH} 2$ by adding $1 \mathrm{~N} \mathrm{HCl}$; two phases are observed at this $\mathrm{pH}$ value: $\mathrm{HA}$ are insoluble in an acid medium precipitate, and fulvic acids (FA) remain soluble in supernatant (Sharif et al. 2002). FA fraction was discarded and HA were separated and subject to freeze drying.

Microorganisms and microbial inoculants. The following bacterial strains were used: CSB3 (Microbacterium sp.), CSB13 (Acinetobacter sp.) and CSB25 (Bacillus mycoides). These strains were previously isolated from microhabitats influenced by waste from the activity of extracting coal in an open cast mine in La Guajira, Colombia, and were selected by evaluating their coal biotransforming activity, which helped to demonstrate that such strains have the ability 
to take LRC as a carbon source and to produce HOM in the process (Valero et al. 2014). In order to obtain sufficient biomass from each of these three strains, a bacterial inoculum was prepared as follows: 2 liters of the sterile liquid culture medium were poured into 5-liter glass jars (nutrient broth $0.8 \%$ + humus alpha ${ }^{\circledR} 0.005 \%$ ) and each bacterial strain was inoculated. The culture was maintained at $30^{\circ} \mathrm{C}$ for 48 hours with continuous air flow. Subsequently, biomass resulting from each of the three cultures was blended to obtain a mixture of the three strains. The resulting mixture was diluted with sterile distilled water in order to adjust a cell concentration of $1.5 \times 10^{9}$ cells $/ \mathrm{mL}$; this solution was used as inoculum for the soil in subsequent experiments.

Immediate adsorption of DDT by pretreated soil with lignite and CSB. An experiment was developed completely at random, with four treatments: only soil, soil $+3 \%$ LRC, soil $+3 \%$ LRC + CSB, and soil $+\mathrm{CSB}$; three repetitions for each treatment were made. Experimental units consisted of containers with $1 \mathrm{~kg}$ of soil without DDT to which the treatments described above were applied; as for treatments with addition of CSB, $300 \mathrm{~mL}$ of inoculum was added. The treated soil was maintained for 30 days by keeping moisture close to the field capacity. After this time, a 20 gram sample was taken and diluted in $100 \mathrm{~mL}$ of a DDT solution concentrated to the water solubility limit $(0.0246 \mathrm{ppm})$. The sample was shaken in an orbital manner at $200 \mathrm{rpm}$ for 2 hours, which was done to ensure the homogeneity of the mixture and allow for adsorption of DDT from the soil, as recommended by Dercova' et al. (2007). Once the shaking was completed, the sample was left to decant for 24 hours and the supernatant was filtered. Then, the remaining DDT in the solution was extracted with cartridges of solid phase extraction (SPE) and its concentration was determined in the aqueous extract by means of high performance liquid chromatography (HPLC). The remaining DDT concentration in the aqueous extract was considered as an indicator of the amount of DDT that was adsorbed by the soil in the different treatments.

For DDT detection, a HPLC Shimadzu chromatograph was used with its diode array detector set at $238 \mathrm{~nm}$, LiChospher ${ }^{\circledR} 100 \mathrm{RP}-18(250 \mathrm{~mm} \times 4 \mathrm{~mm}$ $\times 5 \mu \mathrm{m})$ column, mobile phase for detecting DDT: methanol/water $(90 / 10)$ to $0.5 \mathrm{~mL} / \mathrm{min}$, injection volume: $100 \mu \mathrm{L}$ and retention time of $17 \mathrm{~min}$ (Wang et al. 2012).

Samples were concentrated with chromatographic extraction cartridges in solid phase: 7020-03 Baker- bond $\mathrm{spe}^{\mathrm{TM}} \mathrm{C} 18$ octadecyl. First, the cartridges were activated by passing methanol and then deionized water through them at a rate of two times their volume $(2 \mathrm{~mL})$. Afterwards, the total sample volume was passed through the cartridges. Finally, nonpolar compounds were extracted with $2 \mathrm{~mL}$ of acetone. In all cases, manual pressure was used with the plunger from a $3 \mathrm{~mL}$ syringe. Lastly, the humic content of the soil's aqueous extract was determined, in doing that, extract samples were taken and absorbance was measured at $465 \mathrm{~nm}$ (Valero et al. 2012). This was done in order to compare the content of soluble HOM in the sample.

DDT-soil interaction for 30 days. Effect of applying LRC and CSB on the adsorption of the contaminant. In this experiment, the following treatments were evaluated: only soil, soil $+3 \%$ LRC, soil $+3 \%$ LRC + CSB, soil + CSB and soil + HA. Three repetitions were made for each treatment. For this test, the soil was previously contaminated at $40 \mathrm{ppm}$ of DDT. After 30 days of system interaction (DDTsoil-LRC-CSB) had elapsed, $20 \mathrm{~g}$ samples of soil were taken and diluted in $100 \mathrm{~mL}$ of distilled water which was shaken in an orbital manner at $200 \mathrm{rpm}$ for $2 \mathrm{~h}$ and left to decant for $24 \mathrm{~h}$ and subsequently filtered with Whatman filter paper. Finally DDT was extracted using SPE cartridges and its concentration in the aqueous extract was determined by HPLC, as described for the above test.

DDT level differences in aqueous extracts are indicative of the effect of treatments on the adsorption and bioavailability of DDT.

DDT-soil interaction for six months. Effect of applying LRC and CSB on the adsorption of the contaminant. The same treatments as in the previous experiment were evaluated, but DDT-soil interaction and different treatments went on for six months; experimental units consisted of containers with $200 \mathrm{~g}$ of soil previously contaminated at $40 \mathrm{ppm}$ of DDT. After six months, $100 \mathrm{~g}$ samples of soil were taken and diluted into $1000 \mathrm{~mL}$ of distilled water. This was shaken in an orbital manner at $200 \mathrm{rpm}$ for 2 hours and left to decant for seven days and subsequently filtered with Whatman filter paper. DDT and DDD (dichlorodiphenyldichloroethane) concentration in aqueous extracts filtered from the soil was determined by means of gas chromatography (GC) with an electron microcapture detection system (Agilent 6850), through the ASTM D6520-06 reference method and retention times of 5.220 and $4.947 \mathrm{~min}$ for DDT and DDD respectively. 
Ability of CSB to take DDT as carbon source. A means of solid culture was used with DDT as a carbon source according to the following composition: $\mathrm{mg} / \mathrm{L}$ (Carrillo et al. 2004): $\mathrm{NH}_{4} \mathrm{NO}_{3} 2.50, \mathrm{KH}_{2} \mathrm{PO}_{4}$ $1.75, \mathrm{MgSO}_{4} 0.75, \mathrm{~K}_{2} \mathrm{HPO}_{4} 0.75, \mathrm{NaCl} 0.25, \mathrm{ZnSO}_{4}$ $0.088, \mathrm{FeCl}_{3} 0.08, \mathrm{CuSO}_{4} 0.016, \mathrm{MnCl}_{2} 0.014, \mathrm{MoO}_{3}$ $0.007, \mathrm{Co}\left(\mathrm{NO}_{3}\right)_{2} 0.005$, agar-agar $1.8 \%$ and $92 \mathrm{~mL}$ of distilled water. This solution was subject to heating until becoming dissolved and autoclaved sterilized at $121{ }^{\circ} \mathrm{C}, 15 \mathrm{lb}$ of pressure for $15 \mathrm{~min}$. Afterwards, $8 \mathrm{~mL}$ of a solution of DDT at $500 \mathrm{ppm}$ were added for adjusting to a final concentration of $40 \mathrm{ppm}$ DDT (Carrillo et al. 2004). CSB were cultured in triplicate through this medium and incubated at $37{ }^{\circ} \mathrm{C}$ for seven days. The growth of strains in this medium indicated their ability to take DDT as a carbon source and demonstrated their DDT degradation potential.

\section{RESULTS AND DISCUSSION}

Soil characterization. Table I shows the results of basic characterization of the soil sample used for the experiment. The texture was described as sandy loam (SL), with low clay content, which may be related to a lower capacity to form clay-humic complexes that allow stable immobilization of xenobiotics to the soil matrix (Gevao et al. 2000, Decorva' et al. 2007). The $\mathrm{pH}$ is considered to be acid, which increases the possibility of solubilizing minerals and organic compounds (Jaramillo 2011), reducing its fixation and immobilization on the soil. The content of organic matter is low, which represents for this soil a lesser capacity of adsorption of xenobiotics (Gevao et al. 2000).

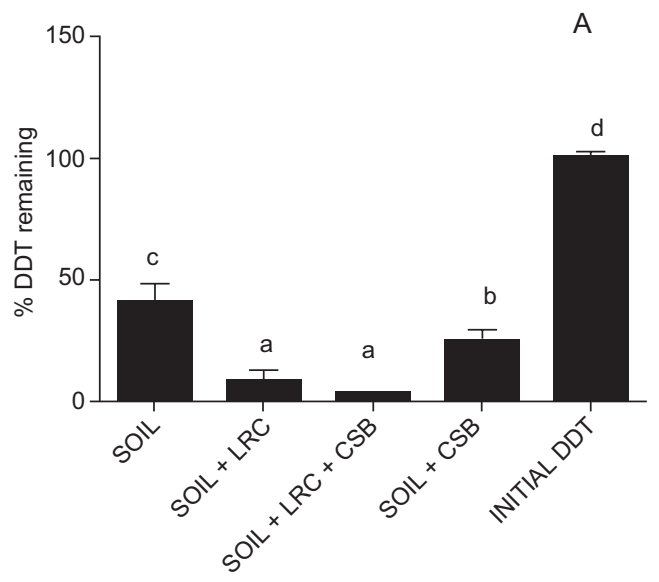

TABLE I. PHYSICAL AND CHEMICAL ANALYSIS OF SOIL USED IN TRIALS

\begin{tabular}{|c|c|c|}
\hline \multicolumn{2}{|l|}{ Property } & \multirow{2}{*}{$\begin{array}{l}\text { Result } \\
73.4\end{array}$} \\
\hline \multirow{3}{*}{ Texture: sandy loam } & Sand $(\%)$ & \\
\hline & Silt (\%) & 15.7 \\
\hline & Clay $(\%)$ & 10.9 \\
\hline \multicolumn{2}{|l|}{$\mathrm{pH}$} & 5.4 \\
\hline \multicolumn{2}{|c|}{ Exchangeable acidity. $\mathrm{cmol}(+) / \mathrm{kg}$} & 0.19 \\
\hline \multicolumn{2}{|l|}{ Base saturation (\%) } & 40.3 \\
\hline \multirow{2}{*}{ Organic matter } & Organic matter $(\%)$ & 0.47 \\
\hline & Total nitrogen $(\%)$ & 0.04 \\
\hline \multirow{6}{*}{$\begin{array}{l}\text { Exchange complex. } \\
\mathrm{cmol}(+) / \mathrm{kg}\end{array}$} & Cation exchange capacity & 4 \\
\hline & $\mathrm{Ca}$ & 0.99 \\
\hline & $\mathrm{Mg}$ & 0.28 \\
\hline & $\mathrm{K}$ & 0.25 \\
\hline & $\mathrm{Na}$ & 0.09 \\
\hline & Total base & 1.6 \\
\hline
\end{tabular}

Immediate adsorption of DDT for pretreated soil with lignite and CSB. By subjecting the concentrated DDT solution to the water solubility limit $(0.0246 \mathrm{ppm})$ to the action of soil untreated, the solution showed a percentage of remaining DDT in dilution of $41.16 \%$ (Fig. 1a). The ability of soil to retain organic contaminants is attributed to adsorption phenomena and to chemical reactions that occur on the surfaces of humic substances and mineral particles (Gevao et al. 2000, Gevao et al. 2002, Fava et al. 2004). Taking into account that the soil under study has a minimum content of organic matter and clays forming the clay-humic complex,

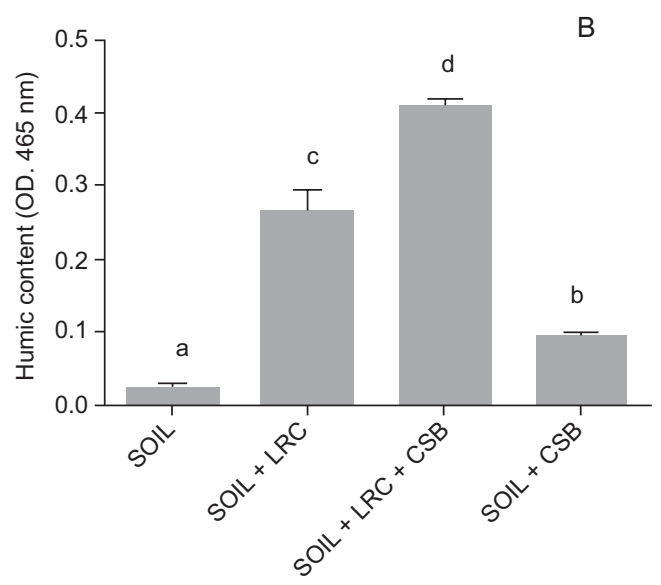

Fig. 1. A. Percent of remaining DDT in the aqueous extracts of soil after treatment with low rank coal (LRC) and coal solubilizing bacteria (CSB). B. Humic content in the aqueous fraction of the soil in different treatments. Lines on bars indicate standard deviation. Different letters indicate significant statistical differences. 
and that such two characteristics are directly related to the adsorption of persistent organic pollutants, it can be considered that this soil could have a greater potential of adsorption of the contaminant after the treatment with the addition of organic amendments.

Soil treatments with addition of LRC, CSB and LRC + CSB caused greater adsorption of polluting than untreated soil and showed statistically significant differences among all treatments, except between LRC and LRC + CSB (differences of simple groups with homogenous variances $\geq 0.05$ ), which showed higher levels of adsorption with percentages of remaining DDT in dilution of $8.16 \%$ and $3.4 \%$, respectively (Fig. 1a). These results may indicate that the presence of LRC on the soil is the main causative factor of the increased adsorption of DDT and the reduction of its bioavailability.

LRCs have some physical and chemical characteristics that provide them with adsorptive properties. Firstly, because of their porosity and high surface contact, LCRs are outfitted with phenomena of physisorption, which allows them to retain molecules. This property has been used to purify waters contaminated with heavy metals or persistent organic contamination (Gan et al. 1972, Yu et al. 2013). Furthermore, due to the humic nature of these coals, their surface possesses chemical groups, which have shown to have the capability to adsorb organic contaminants (Teng and Hsieh 1998, Crosdale et al. 2008). It is noteworthy that in the presence of CSB, there was further reduction in the bioavailability of DDT. These bacteria release HS contained in such coals (Valero et al. 2014), which, for the residual coal, represents an increase in its porosity, which may be related to the increased of its adsorbent activity. A test that is similar to that of the present work reported the reduction of bioavailability of pentachlorophenol by applying zeolite supplemented with humic acids (Dercova' et al. (2007). This phenomenon was attributed to adsorption processes on account of both materials.

On the other hand, it is possible that the reduction in bioavailability is caused by the increased content of HOM in soil due to treatment with LRC (Valero 2013). Xenobiotic organic compounds bind to HOM through various mechanisms, such as formation of covalent bridges, ionic bridges, hydrophobic partitioning, Van der Waals forces, charge transfer complexes, ligand exchanges and hydrogen bonds (Gevao et al. 2000, Dercova' et al. 2007, Mazzei and Piccolo 2012). Therefore, it can be suggested that HOM present in LRC interacted with DDT increasing its immobilization. Fontaine and Piccolo (2012) demonstrated the copolymerization of organochlorine compounds to HS through enzymatic catalysis. It has also been shown that the application of organic amendments rich in HS under experimental conditions stably retains and considerably reduces the bioavailability of contaminants such as $p, p$ - dichlorodiphenyldichloroethylene ( $p, p$ - DDE), preventing its translocation through the plant's roots and vascular tissue (Peters et al. 2007).

It is shown in figure 1b that the absorbance level $(465 \mathrm{~nm})$ evinced by the aqueous extract obtained from control soil is lower, indicating a lesser HOM concentration, which is related to the result in figure 1a in which it is evidenced that this treatment results in lower adsorption of DDT. In the treatment with the addition of LRC there was an increase in absorbance of the aqueous extract at $465 \mathrm{~nm}$, indicating that, on the basis of LRC, HOM fractions were spontaneously released. Previously, Valero (2013) demonstrated spontaneous release of HS from the same type of LRC; however, in the treatment including LRC + $\mathrm{CSB}$, there was greater absorbance. This is possibly because bacteria manage to solubilize LRC and increase HOM in the soil. It was previously demonstrated that these bacterial strains have the ability to achieve the biotransformation LRC releasing HS in the process (Valero et al. 2014). The elemental characterization results of LRC indicate that it can be a usable carbon and nitrogen source (Table II).

Overall, the results of this experiment suggest that treatment of soil with LRC causes the release of HOM and this effect is increased by the presence of CSB; then, the effect on the availability of DDT apparently is caused by the presence of THE, which matches with what was previously described by several authors (Fontaine and Piccolo 2012, Mazzei and Piccolo 2012).

DDT-soil interaction for 30 days. Effect of applying LRC and CSB on the adsorption of the contaminant. Only the soil + CSB treatment showed statistically significant differences (Dunnet $\geq 0.05$ )

TABLE II. ELEMENTAL CHARACTERIZATION OF LOW RANK COAL

\begin{tabular}{crc}
\hline Elemental species & $\%$ & $\mathrm{SD}$ \\
\hline $\mathrm{C}$ & 41.47 & 0.29 \\
$\mathrm{H}$ & 2.57 & 0.17 \\
$\mathrm{~N}$ & 1.54 & 0.04 \\
$\mathrm{O}$ & 31.39 & 0.01 \\
$\mathrm{~S}$ & 0.59 & 0.02 \\
\hline
\end{tabular}

SD: standard deviation 
compared to control treatment (only soil; Fig. 2). This treatment shows a significantly reduction of DDT extracted and quantified. This result suggests the possible degradation of DDT by CSB; Acinetobacter sp. and Microbacterium sp., two of the strains used as inoculum showed ability to grow on solid medium with DDT as sole carbon source. These bacterial strains, in addition to exhibiting ability to produce HS from LRC, are also capable of taking LRC as carbon source (Valero et al. 2011). LRC is a complex carbon source comprised of polyphenolic fractions with structures similar to those of the contaminant under study; in that sense, it is likely that these bacteria may also have the ability to degrade DDT. Other studies have reported the capacity of these bacterial genera to degrade recalcitrant compounds including DDT (Asturias et al. 1994, Dercorva' et al. 2003, Carrillo et al. 2004).

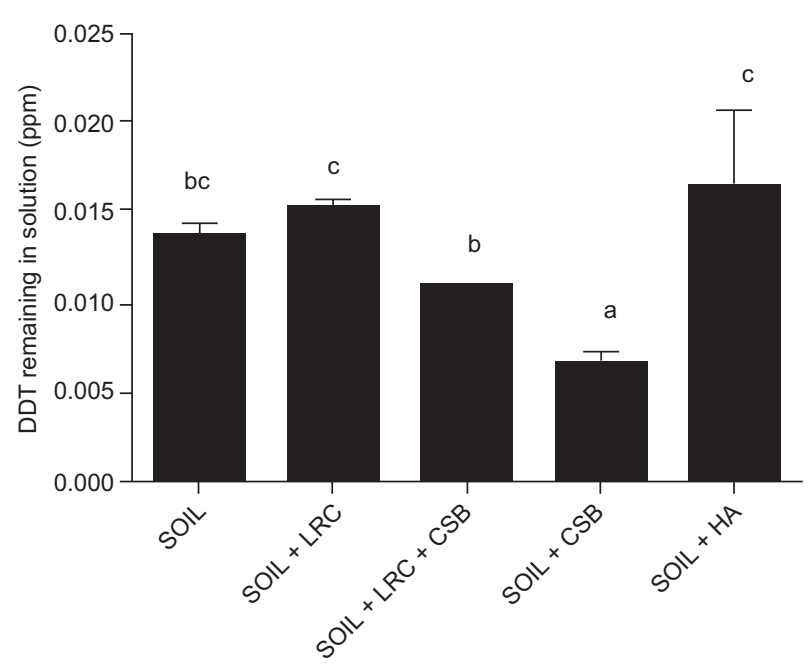

Fig. 2. DDT bioavailable after its direct interaction with the soil treated with low rank coal (LRC) and coal solubilizing bacteria (CSB) for 30 days. Lines on bars indicate standard deviation. Different letters indicate significant statistical differences.

The role of the genus Acinetobacter sp has been widely described in the aerobic biodegradation of biphenyl-chlorinated compounds (PCBs). This activity can occur through three different ways: (a) direct metabolism of the compound, (b) degradation by secondary metabolism; in this method, the bacteria require other sources of primary carbon, and (c) by microbial modification of the compound's structure, making it more susceptible to degradation. Direct bacterial degradation has been described in Acinetobacter sp and is mediated by the biphenyl dioxygenase enzyme (Dercova' et al. 2003, Purnomo et al. 2011).
Additionally, statistically significant differences (Dunnet $\geq 0.05$ ) between treatment with soil + LRC + CBS were observed with respect to treatments involving soil + LRC and soil + HA (Fig. 2), with less bioavailable contaminant concentration in the first (soil $+\mathrm{LRC}+\mathrm{CBS}$ ), indicating that in this experiment the main causative factor for reducing the bioavailability of DDT was CSB application. The differences between the concentrations of DDT in the treatment with CSB and the one that includes LRC + CSB (Fig. 2), indicate that bacteria prefer LRC and HS released from itself as the carbon source, as it is easier to metabolize. It is probable that the reduction of DDT in the treatment including LRC + CSB is generated due to degradation processes by co-metabolism using the HOM from LRC as an alternate source of energy for the degradation of DDT.

The difference of the effect of LRC between the first and second experiments may be that after 30 days of direct interaction of the contaminant with the humic fraction of the soil has submitted a higher solubility of DDT, which may have increased its availability in an aqueous medium. Fava and Piccolo (2002) and Gavrilescu (2005) showed increased bioavailability of PCBs in the presence of humic amendments, thus describing increases in the biodegradability of such compounds. This is due to the fact that extremely hydrophobic molecules such as DDT become more soluble in the hydrophobic domains of humic superstructure (colloidal suspension), increasing the accessibility of contaminants to specialized microorganisms in PCB biodegradation.

The acid $\mathrm{pH}$ of the soil used in this experiment (5.4) could be related to the inability of the soil (even with the application of LRC as an HOM source) to immobilize DDT because the acidic $\mathrm{pH}$ in the soil tends to promote the solubilization of mineral and organic compounds, leaving them free in their aqueous fraction (Jaramillo 2011). The results of this experiment led to the completion of another experiment, whereby the contaminant may interact with the treated soil longer.

DDT-soil interaction for six months. Effect of applying $\mathrm{LRC}$ and CSB on the adsorption of the contaminant. In this experiment, LRC and LRC + CSB showed a significant reduction of bioavailable DDT in aqueous extract of the soil compared to other treatments, but do not differ from each other (Fig. 3a). Thus, the main probable causative factor of the reduction in bioavailable DDT is LRC. Results show differences between the interaction of DDT in soil treated for 30 days and six months. Various 

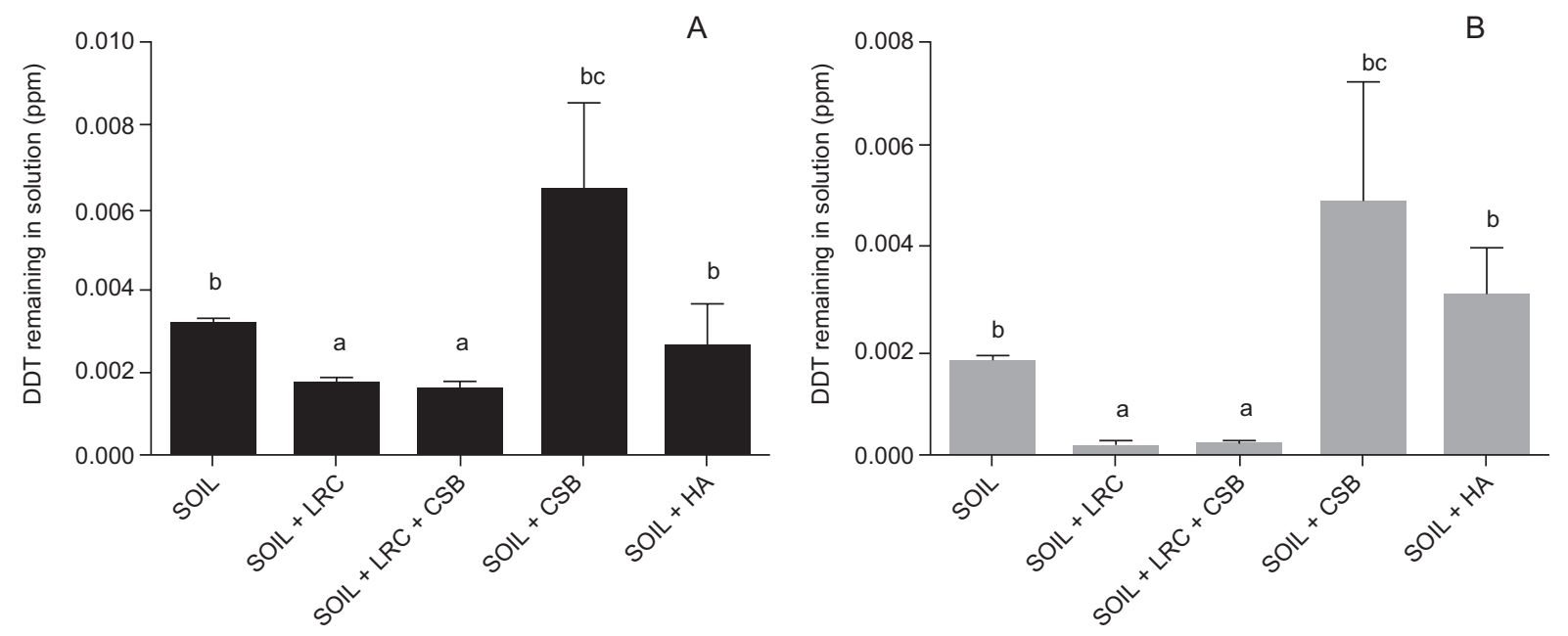

Fig. 3. A) DDT bioavailable after its direct interaction with the soil treated with low rank coal (LRC) and coal solubilizing bacteria (CSB) for six months. B) DDD bioavailable resulting from the transformation of DDT after its direct interaction with the soil treated with LRC and CSB for six months. Lines on bars indicate standard deviation. Different letters indicate significant statistical differences.

researches have shown that the interaction of xenobiotic organic pollutants with soil HS in the presence of peroxidase-type enzymes, and over long periods of time (more than 200 days), affects the immobilization and adsorption of the contaminant by means of co-polymerization processes and "intra-organic diffusion", which involves several physicochemical mechanisms and could become a promising strategy of decontamination in soils contaminated by organic xenobiotics (Hatzinger and Alexander 1995, Alexander and Guerin 1999, Gevao et al. 2000, Nam and Kim 2002, Fontaine and Piccolo 2011, Mazzei and Piccolo 2012). Furthermore, the adsorption capacity of LRCs for a longer timeframe could also have influenced the increase in the reduction of the contaminant's bioavailability.

There were no statistically significant differences between control treatments, soil + CSB and soil + HA. It is probable that after six months the bacterial inoculum may have lost its viability due to the absence of easily assimilated carbon and nitrogen sources (Rodríguez 2003). Although some authors have reported the adsorption of organochlorine contaminants in soil by applying HA (Dercova' et al. 2007, Smejkalová et al. 2009), in this experiment that behavior was not observed. This could be related to HA de-polymerization processes because of the native microbiota, which takes the HA as a carbon source after being added to a soil with low organic matter content. This behavior is known as the "primming" effect (Kleber 2003, Van et al. 2006).

The results of gas chromatography (data not shown) indicated that after six months, the interaction of DDT with soil under various treatments generated a byproduct of the degradation of said compound, known as DDD. The adsorption and bioavailability of this byproduct in different aqueous extracts showed a behavior similar to that of DDT (Fig. 3b), which could be explained by the same adsorption phenomena generated by the addition of LRC and its subsequent release of HS into the soil.

\section{CONCLUSIONS}

The treatment of soil under study with LRC brings about immediate adsorption of DDT, decreasing its bioavailability. This process is related to the adsorptive properties of LRCs and their content of HOM, which is released into the soil spontaneously or by the action of CSB.

The interaction of DDT in soil with LRC and CSB suggests contaminant degradation, while the adsorbent action of LRC or HS released from bacteria is less noticeable; however, after six months, the reduction in bioavailability of DDT occurs due to the application of LRC on the soil. This is explained by the copolymerization of DDT in humic fraction stemming from LRC or due to the adsorption of the contaminant to the coal.

The content of HOM plays an important role in the bioavailability of DDT in soil from the Village of Caracolicito in the department of Cesar with low organic matter content. The use of coal, in association 
with beneficial microorganisms in the soil, represents a promising biotechnology strategy in the rehabilitation of soil contaminated with DDT and probably with other organic xenobiotics.

\section{REFERENCES}

Asturias J., Moore E., Yakimov M., Klatte S. and Timmis K. (1994). Reclassification of the polychlorinated biphenyl-degraders Acinetobacter sp. Strain P6 and Corynebacterium sp. Strain MB1 as Rhodococcus globerulus. Syst. Appl. Microbiol. 17 (2), 226-231. DOI: 10.1016/S0723-2020(11)80012-3

Alexander M. and Guerin W.F. (1999). Biodegradation and bioremediation. 2a ed. Academic Press. San Diego, USA, $455 \mathrm{pp}$.

Carrillo E., Ruiz A. and Yeomans H. (2004). Aislamiento, identificación y evaluación de un cultivo mixto de microorganismos con capacidad para degradar DDT. Rev. Int. Contam. Ambie. 20 (2), 69-75.

Crosdale P.J., Moore T.A. and Mares T.E. (2008). Influence of moisture content and temperature on methane adsorption isotherm analysis for coals from a low-rank, biogenically-sourced gas reservoir. Int. J. Coal. Geology. 76 (1-2), 166-174.

DOI: $10.1016 /$ j.coal.2008.04.004

Dercova' K., Balaz S., Vrana B. and Tandlich S. (2003). Aerobic biodegradation of polychlorinated biphenyls (PCBs). In: The utilization of bioremediation of reduce soil contamination: Problems and solutions (V. Sasek, J.A. Glaser and P. Baveye, Eds.) Kluwer Academic Publisher. Springer, Prague, Czech Republic, pp. 95113.

Dercova' K., Seja'kova' Z., Skokanova' M., Baranc `` 1'kova' G. and Makovnı'kova'. J. (2007). Bioremediation of soil contaminated with pentachlorophenol (PCP) using humic acids bound on zeolite. Chemosphere 66 (5), 783-790. DOI: 10.1016/j.chemosphere.2006.06.061

Fava F. and Piccolo A. (2002). Efect of humic substances on the bioavailability and aerobic biodegradation and polychlorinated biphenyls in a model soil. Biotech. and Bioengineering 77 (2), 204-211.

DOI: $10.1002 /$ bit. 10140

Fava F., Berselli S., Conte P., Piccolo A. and Marchetti. L. (2004). Effects of humic substances and soya lecithin on the aerobic bioremediation of a soil historically contaminated by polycyclic aromatic hydrocarbons (PAHs). Biotech. and Bioengineering 88 (2), 214-224. DOI: 10.1002/bit.20225

Fontaine B. and Piccolo A. (2012). Co-polymerization of penta-halogenated phenols in humic substances by catalytic oxidation using biomimetic catalysis.
Environ. Sci. Pollut. Res. Int. 19 (5), 1485-1493

DOI: $10.1007 / \mathrm{s} 11356-011-0626-\mathrm{x}$

Gan H., Nandi S.P. and Walker P.L. (1972). Nature of the porosity in American coals. Fuel 51 (4), 272-277. DOI: $10.1016 / 0016-2361(72) 90003-8$

Gavrilescu M. (2005). Fate of pesticides in the environment and its bioremediation. Eng. Life. Sci. 5 (6), 497-526. DOI: 10.1002/elsc.200520098

Gevao B., Semple K. and Jones. K. (2000). Bound pesticide residues in soils: a review. Environ. Pollut. 108 (1), 3-14. DOI: 10.1016/S0269-7491(99)00197-9

Gevao B., Jones K.C., Haygarth P.M. and Jarvis S.C. (2002). Pesticides and persistent organic pollutants. In: Agriculture, hydrology and water quality (P.M. Haygarth and S.C. Jarvis. Eds.). CABI Publishing, Wallingford, UK, pp. 83-106.

Gianoulli A., Kalaitzidis S., Savalas G., Atziapostalau A., Christanis K. and Papazisimou S. (2008). Evaluation of greek low-rank coals as potential raw material for the production of soil amendments and organic fertilizers. Int. J. Coal. Geol. 77 (3-4),383-393.

DOI: 10.1016/j.coal.2008.07.008

Hatzinger P. and Alexander M. (1995). Effect of aging of chemicals in soil on their biodegradability and extractability. Environ. Sci. Techno. 29 (2), 537-545.

DOI: $10.1021 / \mathrm{es} 00002 \mathrm{a} 033$

Herrera P., Pantoja M. and Valero N. (2012). Efecto de un carbón de bajo rango y bacterias promotoras de crecimiento vegetal sobre el crecimiento temprano de dos gramíneas forrajeras de interés en el departamento del Cesar. In: Biofertilización: Avances en Investigación (L.A. Castilla, Ed). Sociedad Colombiana de la Ciencia del Suelo. Ibagué, Colombia, pp. 83-94.

Jaramillo D. (2011). El suelo: origen, propiedades, espacialidad. $2^{\mathrm{a}}$ ed. Universidad Nacional de Colombia. Medellín, Colombia, 533 pp.

Kleber M. (2003). What is recalcitrant soil organic matter? Environ. Chem. 7 (4), 320-329.

DOI: $10.1071 / \mathrm{EN} 10006$

Mazzei P. and Piccolo A. 2012. Quantitative evaluation of noncovalent interactions between glyphosate and dissolved humic substances by NMR spectroscopy. Environ. Sci. Techno. 46 (11), 5939-5946.

DOI: $10.1021 / \mathrm{es} 300265 \mathrm{a}$

Ministerio de Medio Ambiente (2007). Consolidación del inventario nacional de plaguicidas contaminantes orgánicos persistentes (COP). Ministerio de Medio Ambiente y Desarrollo Territorial de Colombia. Inventario Nacional. Bogotá, D.C., Colombia, 36 pp.

Nam K. and Kim J.Y. (2002). Persistence and bioavailability of hydrophobic organic compounds in the environment. Geosci. J. 6 (1), 13-21.

DOI: $10.1007 / \mathrm{BF} 02911331$ 
Janoš P., Z'avodsk'a L. and Lesn'y J. (2011). Young brown coals for environmental applications: composition, acid-base, ion exchange, and sorption properties of selected central European coals. In: Coal extraction (J. J. Stewart, Ed). Nova Science Publishers. New York, USA, pp. 71-90.

Peters R., Kelsey J. and White. J. (2007). Differences in $\mathrm{p}, \mathrm{p}$ - DDE bioaccumulation from compost and soil by the plants Cucurbita pepo and Cucurbita maxima and the earthworms Eisenia fetida and Lubricans terrestris. Environ. Pollut. 148 (2), 539-545.

DOI: 10.1016/j.envpol.2006.11.030

Purnomo A.S., Mori T., Kamei I. and Kondo R. (2011). Basic studies and applications on bioremediation of DDT: a review. Int. Biodeterior. Biodegrad. 65 (7), 921-930. DOI: 10.1016/j.ibiod.2011.07.011

Robertson B. K., and Alexander M. (1998). Sequestration of DDT and dieldrin in soil: Disappearance of acute toxicity but not the compounds. Environ. Tox. Chem. 17 (6), 1034-1038. DOI: 10.1002/etc.5620170608

Rodríguez D. T. (2003). El papel de los microorganismos en la biodegradación de compuestos tóxicos. Rev. Ecosistemas 12 (2), 1-5.

Rojas M. (2010). Incidencia y tendencia de seis cánceres en poblaciones expuestas ambientalmente a plaguicidas en desuso en el departamento del Cesar (Colombia). Rev. Col. Cancerol. 14 (2), 88-101. DOI: $10.1016 / \mathrm{S} 0123-9015(10) 70102-5$

Sánchez N., Rodríguez M. and Sarria V. (2006). Pesticidas obsoletos en Colombia, situación actual y alternativas de tratamiento y disposición. Rev. Ing. 23, 13 -23.

Sharif M., Khattak R. A. and Sarir M.S. (2002). Effect of different levels of lignitic coal derived humic acid on growth of maize plants. Comm. Soil. Sci. Plant. Anal. 33 (19-20), 3567-3580. DOI: 10.1081/CSS-120015906

Smejkalová D., Spaccini R., Fontaine B. and Piccolo. A. (2009). Binding of phenol and differently halogenated to dissolved humic matter as measured by NMR spectroscopy. Environ. Sci. Technol. 43 (14), 5377-5382. DOI: 10.1021/es900559b

Stehlickova L., Svab M., Wimmerova L. and Kozler. J. (2009). Intensification of phenol biodegradation by humic substances. Int. J. Biodeterioration Biodegradation 63 (7), 923-927. DOI: 10.1016/j.ibiod.2009.06.007

Sudharshan S., Naidu. R., Mallavarapu M. and Bolan. N. (2012). DDT remediation in contaminated soils: a review of recent studies. Biodegradation 23 (6), 851863. DOI: $10.1007 / \mathrm{s} 10532-012-9575-4$
Tejada M., Gómez I. and del Toro M. (2011). Use of organic amendments as a bioremediation strategy to reduce the bioavailability of chlorpyrifos insecticide in soils. Effects on soil biology. Ecotox. Environ. Saf. 74 (7), 2075-2081.

DOI: 10.1016/j.ecoenv.2011.07.005

Teng H. and Hsieh C.T. (1998). Influence of surface characteristics on liquid-phase adsorption of phenol by activated carbons prepared from bituminous coal. Ind. Eng. Chem. Res. 37 (9), 3618-3624.

DOI: $10.1021 /$ ie $970796 \mathrm{j}$

Tomaszewski J. E., Werner D. and Luthy R. G. (2007). Activated carbon amendment as a treatment for residual DDT in sediment from a superfund site in San Francisco Bay, Richmond, California, USA. Environ. Tox. Chem. 26 (10), 2143-2150. DOI: 10.1897/07-179R.1

Van J., Sun Y. and Coates. J. (2006). Microbial interactions with humic substances. Adv. Appl. Microbiol. 60, 5597. DOI: $10.1016 / \mathrm{S} 0065-2164(06) 60003-8$

Valero N., Beleño J. and Mancilla. S. (2011). Biotransformación de carbón de bajo rango por bacterias aisladas de microhábitats influenciados por residuos de carbón. Rev. Colomb. Biotecnol. 13 (1), 58-65.

Valero N., Rodríguez L.N. and Mancilla S. (2012). Obtención de bacterias biotransformadoras de carbón de bajo rango a partir de microhábitats con presencia de residuos carbonosos. Act. Biol. Col. 17 (2), 335-348.

Valero N. (2013). Transformación microbiana de carbón de bajo rango para inducir cambios en las propiedades del suelo. Ph.D. Thesis. Facultad de Ciencias Agrarias. Universidad Nacional de Colombia. Bogotá, Colombia, $166 \mathrm{pp}$.

Valero N., Gómez L., Pantoja M. and Ramírez R. (2014). Production of humic substances through coal-solubilizing bacteria. Braz. J. Microbiol. 45 (3), 911-918. DOI: $10.1590 / \mathrm{S} 1517-83822014000300021$

Wang X., Xu Q.C., Cheng C. G. and Zhao R.S. (2012). Rapid determination of DDT and its metabolites in environmental water samples with mixed ionic liquids dispersive liquid-liquid microextraction prior to HPLC-UV. Chromatographia 75 (17), 1081-1085. DOI: 10.1007/s10337-012-2278-5

Yu J., Tahmasebi A., Han Y., Yin F. and Li, X. (2013). A review on water in low rank coals: The existence, interaction with coal structure and effects on coal utilization. Fuel. Proc. Tech. 106, 9-20.

DOI: 10.1016/j.fuproc.2012.09.051 